\title{
STRATEGY OF THE STATE POLICY \\ FOR PRESERVATION AND DEVELOPMENT \\ OF LABOR POTENTIAL OF UKRAINE*
}

\section{Iryna Sakharuk ${ }^{1}$ \\ Alina Magomedova ${ }^{2}$ Oleksandra Pohorielova ${ }^{3}$}

DOI: https://doi.org/10.30525/978-9934-26-001-8-2-2

Abstract. The article is devoted to the analysis of the main factors influencing the preservation and development of Ukraine's labor potential, the study of key areas of public policy in this area and the definition of recommendations for its improvement. The condition and current problems of implementation of labor legislation are studied, the ways of reducing unregulated employment are determined; areas for reforming labor legislation in the field of wages, ensuring proper and safe working conditions are identified; the need to increase the role of social dialogue in the regulation of social and labor relations is stressed; the need to improve the system of vocational guidance and vocational training is identified.

The article analyzes the relationship between educational policy and the condition of education at all levels and its impact on the preservation and development of labor potential. Emphasis is placed on the need to revise the system of vocational training by state order, which will help reduce the imbalance of supply and demand in the labor market for certain specialties. Attention is paid to the issues of self-education of employees and lifelong learning.

The authors analyze in the article the demographic situation in Ukraine and the role of demographic policy in preserving and developing the labor

\footnotetext{
${ }^{1} \mathrm{PhD}$ (Law), Associate Professor of the Department of Labour Law and Social Security Law, Taras Shevchenko National University of Kiev, Ukraine ${ }^{2} \mathrm{PhD}$ (Economics), Associate professor of the Department of Business Economics, Taras Shevchenko National University of Kiev, Ukraine

${ }^{3} \mathrm{PhD}$ (Law), Assistant of the Department of Labour Law and Social Security Law, Taras Shevchenko National University of Kiev, Ukraine
}

\footnotetext{
* This scientific research has been performed within the framework of the state budget project № 19БФ042-01M "Socio-Legal Principles of Preservation and Development of Labor Potential of Ukraine", being funded from the Ministry of Education and Science of Ukraine
}

(C) Iryna Sakharuk, Alina Magomedova, Oleksandra Pohorielova 
potential of Ukraine. One of the factors that also affect the preservation and development of Ukraine's labor potential is the high level of external labor migration. Special attention is paid to issues related to the educational migration of Ukrainian citizens.

The conclusions emphasize the need to develop a comprehensive "Strategy for the preservation and development of labor potential of Ukraine", which will include:

1. The normative component determines the legal provision for the preservation and development of labor potential. It is based on labor and social legislation that establishes the level of protection of persons who exercise or may exercise their right to work in the future. At the same time, the normative component is the whole set of normative-legal acts that will regulate practical steps to the preservation and development of labor potential, including the definition of state policy in this direction.

2. The economic component includes the analysis of economic policy of the state as a whole; determining the economic opportunities of society and the individual in Ukraine, their relationship with similar opportunities that exist in the realization of the labor potential of the individual abroad; establishment of favorable and unfavorable conditions that affect the development of labor potential of the state and society.

3. The educational component provides an analysis of the market of educational services, its compliance with the requirements and challenges of the labor market; determination of qualification requirements and skills of graduates, most necessary from the position of the employer; establishing ways to balance supply and demand in the labor market through educational policy, in particular, shifting the emphasis from the theoretical to the practical component of training within vocational and higher education; development of an adult education program (lifelong learning). An important area of educational policy is measures aimed at reducing the level of educational migration.

4. The migration component is an analysis of the migration policy of Ukraine and identification of ways to reduce the level of labor migration of workers and the outflow of qualified personnel.

5. The demographic component includes identifying ways to improve the demographic situation of Ukraine and its individual regions as a factor that directly affects the labor potential of the state in the future. It also 
includes health policy, in particular, the study of factors influencing the health of the population, ways to improve the quality and accessibility of medical services, the introduction of compulsory state health insurance.

\section{Introduction}

An important element of sustainable development of any state is the labor potential, but it should be noted that today in Ukraine there is a decrease in the number of labor resources, and a systematic government policy aimed at their preservation and development is absent. Development and adoption of a comprehensive program for the preservation and development of labor potential of Ukraine should be an operational priority of state social policy, which can be implemented only "on the basis of coordination of all concerned authority, including in the field of education, employment and labor services, migration agencies, etc." [1, p. 225].

Practical actions, which will be aimed at the development of labor potential, will have an unconditional positive effect primarily on the economic situation in Ukraine. We agree with A.V. Sokolov that the efficiency of the functioning of labor potential of society has a direct «exit» to the living standards of the people, because the higher the efficiency of living labor of employees, the greater their contribution to national wealth and personal income, and, consequently, higher living standards [2, p. 12]. Labor resources are capital, which always is a driving force for improving the economic situation of the state and the welfare of society [3].

The purpose of the article is to identify key areas of public policy aimed at preserving and developing the labor potential of Ukraine and analysis of the main issues affecting the formation of public policy in a particular area.

The authors set the main research task of developing a strategy for the preservation and development of labor potential of Ukraine, with the key analysis of the factors influencing the inhibition of its development. Implementation of measures to influence these factors will determine the priority directions of state socio-economic policy for the preservation and development of labor potential.

The key factors influencing the development of labor potential of Ukraine are:

- condition of socio-economic protection of employees: the level of unemployment, wages, occupational injuries, off-the-books employment, 
issues of vocational guidance that affect the balance of supply and demand in the labor market;

- condition of education at all levels, and, in particular, at the level of training within vocational and higher education, compliance of knowledge and skills of graduates with the requirements of employers;

- demographic situation, in particular trends in births, deaths, life expectancy, as well as the state of health of the population, including health care;

- level of external labor and educational migration.

While performing the article, the authors used general and special methods of scientific research. The methodology is based on general scientific dialectical method of cognition and abstract-logical method, which is used to make theoretical generalizations and draw conclusions, methods of analysis and synthesis to determine the factors influencing labor potential and developing the main directions of preservation and labor potential of Ukraine. Statistical data of the State Employment Service, results of sociological surveys, etc. were used as empirical data in the work.

\section{Socio-economic protection of employers}

First of all, the labor potential is influenced by the condition of development of labor legislation, its compliance with international labor standards and the state of compliance. Improvement of labor legislation is one of the areas necessary for the preservation and development of labor potential of Ukraine in accordance with the Concept of the National Targeted Social Program for the preservation and development of labor potential of Ukraine for the period up to 2017 [4].

The decision of the National Trilateral Socio-Economic Council "On Preservation and Development of Labor Potential of Ukraine" emphasizes the need to ensure labor market reform, the introduction of new active measures in the labor market aimed at meeting the needs of employers and employees [5]. Indeed, nowadays the situation on the labor market in Ukraine remains difficult.

According to the State Statistics Service, as of June 2020, the level of employment of people of working age is $66.1 \%$, although the same figure reached $67.2 \%$ for the same period last year [6]. The level of unemployment (according to the methodology of the International Labour Organization) is 


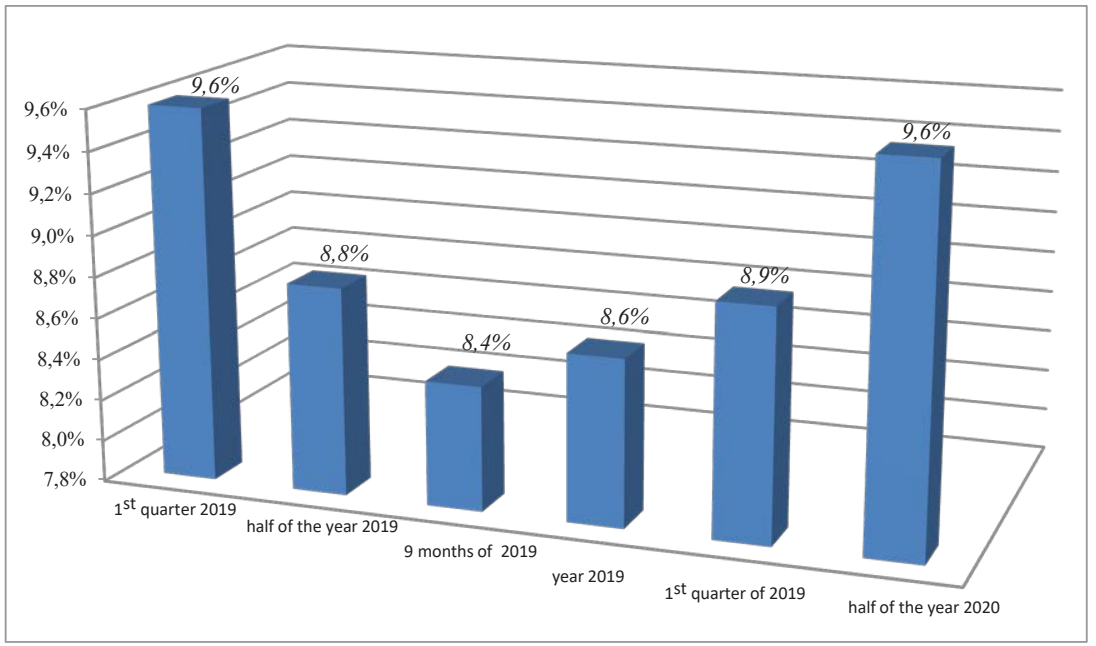

Figure 1. Dynamics of unemployment of the working age population in Ukraine in 2019-2020, \% Source: generated according to data [16]

$9.6 \%$, in $2019-8.8 \%$ [7]. We observe a clear positive trend of increasing unemployment in Ukraine since the 3rd quarter of 2019 and till present day in Figure 1. It is obvious that by the end of the year, taking into account the consequences of the pandemic and the restrictive quarantine consequences, the number of unemployed will only increase, which will only worsen the already critical situation on the labor market. According to results of annual reports of the Ministry of Economic Development and Trade of Ukraine, a third of the Ukrainian economy is in the shadows and every third person in Ukraine works in the shadow sector [8].

As M.V. Vinichuk emphasizes, the level of employment and unemployment are the main indicators of economic security in the social sphere. Employment reflects the level of use of labor resources and opportunities for economic development of the country, at the same time it is one of the mechanisms of socio-economic security of the country, which determines the parameters of effective functioning of social and economic structures in global and local transformations [9, p. 22]. 
The Decree of the President of Ukraine "On the main directions of labor potential development for the period up to 2010" specifies that the development of labor potential in the field of employment should provide the creation of logistical and socio-economic preconditions for productive employment of the population, the government regulation of labor market regulation is main in creation such preconditions [10]. The priority directions of state regulation of the labor market, aimed at developing labor potential, are: 1) assessment of the general need for workplaces in the country's economy and the formation of the market of professions; 2) job placement on the basis of broad development of small and medium business, selfemployment under the conditions of formation of an effective investment and financial mechanism; 3 ) maximum legalization of unregulated employment; 4) introduction of a mechanism to stimulate job placement for certain sociodemographic groups; 5) reducing the level and duration of unemployment through the implementation of active employment policies, in particular through public works; 6) increasing the territorial mobility of the population in order to redistribute labor between the under-employed and redundant regions; 7) creation of legal and socio-economic grounds for the regulation of external labor migration of citizens of Ukraine, as well as control of the impact of immigration processes on national and regional labor markets [10].

Improving the situation on the labor market, reducing unemployment necessitates the implementation of effective state economic and social policies, including the improvement of labor legislation to combat unregulated employment, encouraging employers and employees to formalize employment relationships. Among the measures aimed at reducing the level of unregulated employment, important are measures, defined by the decision of the National Trilateral Socio-Economic Council "On Preservation and Development of Labor Potential of Ukraine" as of April 05, 2018: 1) development of a draft of legal act on implementation of Recommendations of International Labour Organization on employment relationship as of May 31, 2006 № 198 in terms of determining the features of the existence of labor relations; 2) ensuring the analysis in order to identify areas of economic management in regions with high risks of using the labor of employees without proper registration of labor relations and taking measures to conduct inspection visits in these areas of economic management [5]. 
Reduction of undeclared work is one of the priority areas of activity of the State Labor Service of Ukraine, which is carried out, in particular, in the framework of the technical cooperation project "Strengthening labor administration to improve working conditions and overcome undeclared work" of EU / International Labour Organization. The report "Undeclared work in Ukraine: forms of manifestation, scale and ways to reduce it" identifies that the most relevant forms of undeclared work in Ukraine are: 1) off-the-books employment in the formal sector; 2) employment in the informal sector; 3) concealment of actually worked working hours and payment of envelope wages; 4) replacement of actual employment agreements by civil and economic ones, as well as factitious use of remote and outsourcing mechanisms to conceal wage labour; 5) secondary employment of persons who have a registered employment relationship at the main place of work, not executed in an appropriate manner [11, p. 12].

It is impossible today to determine accurate estimates of the Ukrainian volume of the third main form of undeclared work - the part of wages hidden from the government. The most reliable estimates show that the total amount of hidden wages is approximately equal to $85-90 \%$ of the declared one. The share of employees of formal sector enterprises in respect of which a reasonable assumption can be made about the probability of concealment of the share of wages is equal to $12.4 \%$ of all employees of these enterprises. Even approximate estimates of the volume of the fourth form of undeclared work (replacement of employment agreements by civil law) and the fifth form (secondary employment) are currently missing in Ukraine. Obtaining of these agreements requires special field research or making appropriate changes to the questionnaire for the survey of economic activity of the population of Ukraine [11, p. 14]. These data indicate a significant scale of the problem of the spread of undeclared work in Ukraine, which requires a purposeful government policy to overcome it.

The report "Undeclared work in Ukraine: forms of manifestation, scale and ways to reduce it" emphasizes the feasibility of defining the concept of "undeclared work" and developing a methodology for measuring it to develop a national policy and action plan to reduce it. This will contribute to the observance of labor rights and social guarantees for employees, as well as to the elimination of unfair competition in the market and the elimination of financial risks for the state budget and the social security 
system. The State Labor Service of Ukraine, which performs the function of labor inspection, should play a significant role in reducing undeclared work [11, p. 15].

We agree with M.V. Torzhevsky that the policy of de-shadowing of employment of population should be aimed primarily at eliminating the main motives that provokes the spread of off-the-book employment. The results of a sociological survey of the population and employers showed that such motives are due to the possibility of receiving higher wages compared to the formal sector, additional earnings, income from state social benefits related to poverty, etc. for employees, and for employers - the desire to evade the payment of taxes and the Single Social Contribution, distrust of the state budget policy, the complexity of tax and accounting, low social responsibility to employees, a sense of impunity for violating the law through connections with corrupt officials or crime [12, p. 173]. Legal ignorance of the procedures for formalization of labor relations; difficulties in accessing the normal labor market, unemployment and social dumping are among the reasons for the spread of undeclared work by employees. On the part of employers, this can also be a legal necessity, as well as, for the most part, an attempt to reduce labor costs, and thus the production of goods and services in order to obtain unfair competitive advantages in the market [11, p. 71]. Reasons of distribution of undeclared labor by the state mainly related to imperfect legislation, including its inconsistency with the requirements of the labor market. Also, bureaucratization of procedures for the administration of business and labor relations, reporting, etc.; unattractive level of social protection, when the amount of benefits does not motivate to pay contributions, etc.; low efficiency of regulatory authorities and insufficiently severe sanctions that do not encourage compliance with the requirements set by law belong to the reasons from the side of the state [11, p. 71].

Weighed economic policy has significant importance for reducing of undeclared work along with improvement of legislation. M.V. Torzhevsky suggests to adapt the main approaches to the policy of de-shadowing of employment used in developed countries of the EU, Poland and Georgia and aimed at reducing the financial attractiveness of off-the-book employment, improving the regulatory framework and administration, strengthening the mechanism of supervision and control. In particular, it is necessary to promote the creation of modern highly paid jobs in the formal sector, optimize 
the burden on the payroll, simplify the tax administration system, reform the pension system, combine amnesty to legalize employment with further sanctions against violators of labor legislation. All together, this will increase confidence in state institutions, ensure a gradual reduction in off-the-book employment and accelerate Ukraine's integration with the EU [12, p. 172].

It is necessary to reform a system of remuneration in addition to reducing undeclared work, to enhancing social and economic security of employees. The decision of the National Trilateral Socio-Economic Council "On the preservation and development of labor potential of Ukraine" as of April 04, 2018 indicates the need of further reforming of the wage policy in order to increase income from employment [5].

Increasing the level of wages is one of the most acute problems of the modern labor market of Ukraine, which is due to a significant lag in this indicator from the standards of developed countries and is a factor in the flow of labor to the shadow sector [12, p. 88]. In Ukraine monthly minimum wage has the lowest level in the EU. It' s emphasized that as of 1 January 2020, 21 out of the 27 Member States of the European Union (EU) have national minimum wages: only Denmark, Italy, Cyprus, Austria, Finland and Sweden do not have any. For instance, monthly minimum wages generally below $€ 600$ in east and above $€ 1500$ in northwest of the EU.

In January 2020, Bulgaria had the lowest gross minimum wage (€312) across the EU. Nine Member States, predominantly located in the east of the EU, followed with minimum wages between $€ 400$ and around $€ 600$ per month: Latvia (€430), Romania (€466), Hungary (€487), Croatia (€546), Czechia (€575), Slovakia (€580), Estonia (€584), Lithuania (€607) and Poland (€611). On the other hand, States, located in the west and north of the EU, minimum wages were above $€ 1500$ per month: France ( $€ 1539)$, Germany ( $€ 1584)$, Belgium ( $€ 1594)$, the Netherlands ( $€ 1$ 636), Ireland (€1 656) and Luxembourg (€2 142).

For comparison, the federal minimum wage in Ukraine in the beginning of the 2020 was $155 €$. It's twice lower than minimum level in the EU and in 13,8 times lower than the highest level of minimum wage in the EU (Figure 2) [13].

In Ukraine, the incentive function of wages is almost completely lost for the vast majority of employed citizens it does not contribute to the quality reproduction of labor, does not provide the employee with consumption of material goods and services sufficient to expand his physical and intellectual 


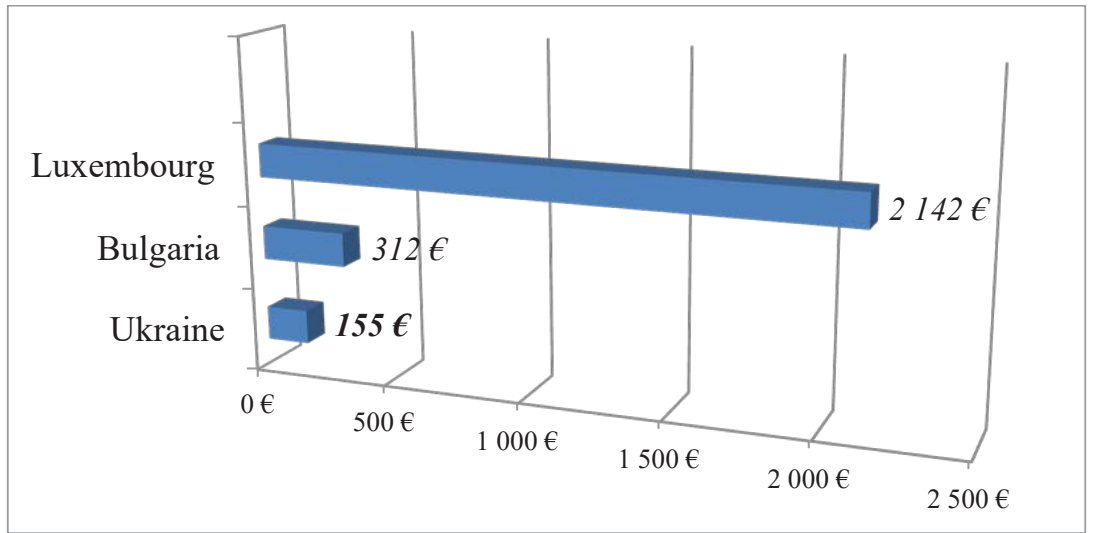

Figure 2. The federal minimum wage in Ukraine and in the $\mathbf{E U}$ (min and max minimum wages), $€$

Source: generated on [33]

ability to work. The level of wages in the country is low, which does not contribute to economic growth, so wages should be gradually increased in order to stimulate the growth of its productivity [3].

Reforming in the field of wage conducted at end of 2016, levels out more the stimulating function of wages. According to the Law of Ukraine "On Amendments to Certain Legislative Acts of Ukraine" as of December 06, 2016 [14], amendments were made to the Law of Ukraine "On Remuneration of Labor" as of March 24, 1995: the approach to the normative definition of the minimum wage was changed. If the minimum wage was earlier defined as a reward for simple unskilled labor, today - it is defined as the statutory minimum wage for the employee's monthly (hourly) rate of work.

Thus, "a skilled employee is now allowed to pay as much as an unskilled worker and set a salary lower than the minimum wage, as it is important that the total payments (basic, additional salary, bonuses, surcharges) are not less than the minimum wage". This negatively affects the motivation to work in a registered economy and to increase the educational and qualification level of employees" [12, p. 88-89].

In this case, as G.S. Lopushnyak rightly notes, while characterizing the change in the definition of "minimum wage", it makes significant 
changes in the formation of the tariff grid. If earlier the tariff rate of the employee of the first category which is a basis for formation of a tariff grid, had to be established "in the size exceeding the legally established size of the minimum wage", now "the minimum official salary (tariff rate) is established in the size not less than subsistence level for ablebodied persons". At the same time, due to a significant understatement of the officially approved subsistence level (53.4\% in December 2016), the salary of an employee of the first tariff category remained twice lower than the minimum wage, thus lowering the salaries of senior employees by $52 \%$. tariff categories. Accordingly, the establishment of the salary of the first tariff category at the level of artificially low subsistence level does not provide differentiation of salaries according to the professional level and leads to "equalization" in the remuneration of employees of 1-11 tariff categories [15, p. 134-135].

An important criterion that characterizes the wage system is the ratio of minimum and average wages, or the Keitz index. The ratio, recommended by the International Labour Organization, correlation of the minimum to average wages is $50 \%$, and the Council of Europe's Committee on Social Rights sets it at $60 \%$. However, as a rule, the Keitz index ranges from $40-50 \%$ in developed countries [12, p. 90]. In Ukraine, as of the end of January 2017 , it is $36.5 \%$ according to the NBU [16]. The change in the approach to determin the minimum wage has allowed to increase this indicator, however, such an increase should be considered artificial, including due to the understatement of the subsistence level in Ukraine (as of July 1, 2020, it is 2,118 UAH, and since December 1 it is expected to increase to $2189 \mathrm{UAH}[17])$.

It is necessary to agree with M.V.Torzhevsky, that the government did not take into account the impact of the minimum wage on unemployment and the spread of off-the-book employment. The rapid increase in the minimum wage leads to a reduction in unskilled workers, for whose welfare this measure is mainly intended. Higher growth rates of the average monthly wage compared to GDP and labor productivity affect the transfer of workers to off-the-book employment [12, p. 89]. Therefore, in order to create effective mechanisms for the development of labor potential, it is necessary to pursue a balanced state policy that will take into account, inter alia, the state of Ukraine's economy. At the same time, wages should 
perform a reproductive, stimulating function, motivating employees to develop personal potential in the performance of labor functions.

An important aspect of reforming of labor law is ensuring of proper and safe working conditions. Thus, the Decree of the President of Ukraine "On the main directions of development of labor potential for the period up to 2010" identifies the need, among the tasks in the field of labor protection, to 1) reduce the level of occupational injuries and occupational diseases; 2) reduce the factors of harmful effects on the body of employees and reducing the number of jobs with harmful and difficult working conditions; 3 ) improve the efficiency of the current management system of labor protection at all levels [10].

The Concept of the National Targeted Social Program for Preservation and Development of Labor Potential of Ukraine for the period up to 2017 emphasizes the need to implement international standards on working conditions and safety at work [4]. This task is detailed in the decision of the National Trilateral Socio-Economic Council "On Preservation and Development of Labor Potential of Ukraine", which determines the need to pay attention to the problems of labor protection and ensure: 1) strengthening of responsibility for violating the legislation of Ukraine on labor protection employers and officials of enterprises, institutions and organizations; 2) approval of the Procedure for investigation and accounting of accidents, occupational diseases and accidents at work in the new edition; 3 ) development and approval of the Concept of reforming the occupational health and safety management system in Ukraine and the action plan for its implementation taking into account the objectives set by the European Union Framework Strategy for Health and Safety at Work for 2014-2020 [5, clauses 1.5, 1.6].

Simultaneously it is necessary to change the approach to understand the institution of labor protection with the need to implement international labor protection standards into national legislation, world experience shows that the right to fair and safe working conditions also includes protection against psychological harassment in the workplace, while national legislation is stored only understanding safety as compliance with safety, industrial hygiene. We agree with the position on the need to expand in modern conditions the content of the institute of labor protection and the inclusion of norms to ensure a comfortable working environment, which will guarantee the psychological integrity and safety of the employee [18, p. 685]. 
S.V. Vyshnovetska rightly emphasizes that among the factors that threaten the safety of the employee, first of all, it is necessary to highlight stress, unfavorable socio-psychological climate in the team, vertical and horizontal mobbing, sexual harassment. Psychosocial risks and stress at work are among the most difficult issues among occupational safety and health. Therefore, the production environment should be organized so as to ensure not only the physical safety of the employee, but also the psychological comfort of his work $[19$, p. 35-36]. So, right on healthy and safe working conditions should include the employer providing not only physical, but psychological conditions [20, p. 116]. At the same time, it is necessary to normatively define the mechanism of counteraction to psychological harassment in the workplace, because today the labor legislation of Ukraine does not actually regulate this issue.

In addition to directly improving of the labor legislation, increasing the effectiveness of social dialogue is a key part in the development of labor potential. The Concept of the National Targeted Social Program for Preservation and Development of Labor Potential of Ukraine for the period up to 2017 emphasizes the need to increase the role of social dialogue in shaping public policy and ensure the implementation of the principles of equality of its participants [4]. Among the measures aimed at preserving and developing labor potential, in the decision of the National Trilateral SocioEconomic Council "On preservation and development of labor potential of Ukraine" [5] a significant place is given to recommendations to the parties to the social dialogue. Among them, the following can be noted: 1) to accept the implementation of the principles of corporate social responsibility; 2) to focus joint efforts on reducing informal employment and de-shadowing the economy through legalization of wages; 3) to development of professional standards, development of a lifelong learning system; 4) to conduct an effective dialogue on the labor market; 5) to arrange the broad informational and explanatory work among the population on labor rights and ways to protect them, the benefits of legal employment [5].

Another important area of legal regulation, in the context of preservation and development of labor potential, is vocational guidance and vocational training. The imperfection of career guidance work in Ukraine leads to a significant imbalance of supply and demand in the 
labor market, the lack of qualified personnel in some specialties and their excess over others. T. Belous's remarks about the need to make forecasts of the quantitative and qualitative composition of labor potential in order to meet the real needs of the labor market in qualified specialists in accordance with the demand for certain professions are fair [21, p. 44]. M.V. Kravchenko emphasizes that the main factor influencing the process of forming high-quality labor potential of the country is professional orientation. It is purposeful career guidance work of educational institutions, public employment service and employers will promote the right choice of profession, which will bring the balance of supply and demand in the domestic labor market, as well as creating competitive advantages of the domestic labor market [3].

\section{Condition of education at all levels and its impact on the preservation and development of labor potential}

Public education policy significantly affects the situation in the labor market, as it allows ensuring of compliance or non-compliance of knowledge and skills of graduates with the requirements of employers, and, accordingly, their demand and competitiveness in the labor market. Thus, the Concept of the National Targeted Social Program for Preservation and Development of Labor Potential of Ukraine for the period up to 2017 emphasizes the need to increase educational and qualification potential, create conditions for further education, gain knowledge and skills during employment, improve the quality of higher and professional training educational institutions [4].

The key areas, among the areas of preservation and development of labor potential in education, as per to the Decree of the President of Ukraine "On the main directions of labor potential development until 2010", in our opinion, are the following: 1) promoting professional selfdetermination and effective adaptation of youth to conditions of market economy; 2) strengthening the orientation of the system of vocational, higher and postgraduate education on training, retraining and advanced training in accordance with the needs, first of all, regional labor markets; 3) arrangement of a system of lifelong learning through the introduction of advanced training, ensuring the implementation of training programs and retraining, creating conditions for self-education; 4) integration 
of vocational, higher and postgraduate education of Ukraine into the international educational system [10].

Revising the system of vocational training as per state order will help reduce the imbalance of supply and demand in the labor market for certain specialties. In accordance with the decision of the National Trilateral Socio-Economic Council "On Preservation and Development of Labor Potential of Ukraine" it is recommended to: 1) promote dialogue and cooperation of vocational education institutions with employers and trade unions by intensifying their participation in developing professional and updating educational standards; vocational education and training; 2) to improve the mechanism of formation of the state and regional order for training of experts, scientific, scientific and pedagogical and working shots according to demand in the labor market; 3) to give instructions to the Ministry of Economic Development together with the relevant ministries and departments to carry out the formation of a state order for the training of specialists, scientific, scientific-pedagogical and labor personnel, taking into account the forecast of labor market needs [5].

It is important to improve the quality of educational programs and professional development programs by ensuring access to education through the development of distance learning, postgraduate education, orientation of education to independent and creative thinking, responsible decision making $[21 ; 44]$. Thus, the decision of the National Trilateral Socio-Economic Council "On Preservation and Development of Labor Potential of Ukraine" emphasizes the need to modernize the educational space (including technical equipment of educational institutions), update information and methodological materials, provide conditions for professional development of teachers composition, etc. [5].

One of the key tasks in the field of education, which requires special attention in the context of labor potential development - the creation of conditions for self-education of employees and lifelong learning. M.V. Kravchenko notes that an important trend that should be borrowed to preserve and develop the labor potential of Ukrainian society is the cultivated understanding of Europeans about the need to learn throughout life. According to a survey conducted in the EU, the vast majority of respondents $(88 \%)$ believe that regular education and training to improve skills or acquire new skills improve their employment prospects [3]. 
"Lifelong learning" is a continuous process of acquiring knowledge, development of professional and personal competencies, which is carried out through various forms of education and self-education and provides the opportunity for self-realization of the individual at different ages [22, p. 233]. The concept of lifelong learning as an important way to increase competitiveness in the labor market appeared in Europe in the $1960 \mathrm{~s}$ and was implemented through various educational and training initiatives, including the Lifelong Learning Program. 2007-2013.

The European Employment Strategy as of July 22, 2003 set out guidelines for lifelong learning policies, which identified the need for EU countries to address skills shortages with relevant skills and encouraged them to pursue comprehensive lifelong learning strategies to equip citizens with the skills needed in today's economy. The guidelines determine the need to increase investment in human resources, especially through adult education enterprises [23].

According to Art. 10 Law of Ukraine "On Education" as of September 05, 2017 the components of the education system in Ukraine are adult education, including postgraduate education [24]. Adult education is a component of lifelong learning and aims to realize the right of every adult to lifelong learning, taking into account his personal needs, priorities of social development and the needs of the economy, can be formal, informal and informal. The components of adult education, according to the Law, include: 1) postgraduate education; 2) professional training of employees; 3 ) retraining and / or advanced training courses; 4) continuous professional development; 5) any other components provided by law, proposed by the subject of educational activity or independently determined by the person [24].

As G.V. Kozlovska rightly notes, Ukraine has clearly defined the benchmark for entering the educational and scientific space of Europe, modernizes educational activities in the context of European requirements. But the once well-organized system of advanced training and retraining in Ukraine is a thing of the past. No new system has been created to meet the needs of a market economy. Therefore, a very important pan-European principle of "lifelong learning" can not be fully implemented in the conditions of our country so far [25, p. 19]. 


\section{Demographic situation as a factor influencing the preservation and development of labor potential of Ukraine (trends in births, deaths, life expectancy)}

As Yu.Yu. Kolos notes, it is necessary to create conditions for increasing fertility, the best spiritual and physical growth of youth, full use of labor, reliable care for health and moral and psychological condition of people from birth to death for the formation, use and preservation of labor potential in society. Only in this case we can assume that the preservation and development of labor potential will be a strategic task for the preservation of sustainable development of Ukraine [1, p. 226].

In recent years, Ukraine has been characterized by a deteriorating demographic situation, there is a problem of population decline and the aging of the nation.

As O.A. Palienko emphasizes, the demographic situation in Ukraine is characterized not only by depopulation, it has become an acute demographic crisis, the main signs of which are adverse changes not only in the number but also in the health of the population. The current demographic situation can be defined as a crisis precisely because depopulation is accompanied by a significant deterioration in human health, which is manifested in a decrease in life expectancy. The trend of significant deterioration in the health of children and adolescents is progressing. The problem of improving the health of the population today has become a problem of its basic preservation. This situation is caused primarily by insufficient funding of the medical sector and the inability of the latter to provide timely and quality medical care to the population [26, p. 134].

In order to improve the demographic situation, the government needs to direct socio-economic policy to address the most pressing issues: stimulating the birth rate, improving health care, strengthening health and wages, improving living conditions and introducing a healthy lifestyle, creating a wide network of public and private social services [26, p. 135].

In the context of demographic policy, $\mathrm{T}$. Belarus also emphasizes the need to achieve an acceptable level of quality of working life, as well as creating conditions for prolonging the active period of working life of groups older than working age [21, p. 44]. It is important to reform the health care system, as well as increase funding for this area. Moreover, in the conditions of rapid aging of the population, the need for funds 
for health care and social security of the elderly is constantly growing $[26$, p. 135]. At the same time, it is important to introduce compulsory state health insurance in Ukraine, as well as to improve the management of labor protection in order to reduce the level of occupational injuries.

Annual population decline occurs in many countries. Due to this negative trend, the governments of some countries pursue appropriate migration policies, seeking compensation for losses due to migrants [26, p. 133].

\section{External migration as a factor influencing the preservation and development of Ukraine's labor potential}

Large-scale surveys of external labor migration of Ukrainians according to the international methodology and with the participation of international organizations were conducted three times by the State Statistics Service of Ukraine: in 2005-2008, in 2010-2012 and in 2015-2017. According to the latest report, in 2015-2017, 1.3 million Ukrainian citizens were abroad to earn money it is only 100,000 more than in $2010-2012$. However, it is obvious that the real scale of labor migration is larger than the State Statistics Service estimated due to certain methodological limitations [27]. Thus, according to a study by the Center for Ukrainian Strategy, published in April 2018, Ukraine is among the top ten donor countries for international migrants in the world. According to various estimates, the number of migrant workers ranges from 0.7 to 4 million people ( $16 \%$ of the working population). At the same time, about 2.6-2.7 million people may be outside the country [28, p. 3].

High level of external labor migration, as M.V. Kravchenko emphasizes, is due to a number of reasons: 1) the problem of employment in accordance with the acquired education of appropriate qualifications with adequate remuneration for work; 2) declining demand for labor due to excessive imports of goods, low wages in the country and arrears of payment, insufficient social guarantees and social protection [3].

According to a survey conducted by the sociological group "Rating" in September $2017,61 \%$ of respondents said they would not like to go abroad for permanent residence, while 35\% expressed such a desire, another $4 \%-$ did not decide the answer. At the same time, $44 \%$ of respondents expressed a desire to work / get a job abroad, but this figure differs significantly depending on the age of respondents: among young people $-68 \%$, among middle-aged people $-52 \%$, and among the oldest $-20 \%$. The main 
motivation for wanting to work abroad was often mentioned by respondents with a higher salary in other countries $(72 \%)$, better working conditions, realization as professionals, higher quality of social protection (from 16 to $20 \%$ of respondents) [29].

Working conditions of Ukrainian labor migrants abroad are characterized by a low level of formalization of labor relations and social protection (excluding sick leave and vacation) and a longer working week than in Ukraine. In 2015-2017, only 38\% of migrant workers had a written employment contract with foreign employers, with the exception of the Czech Republic and Portugal, where the level of formalization of migrant employment is quite high (over 50\%). The low level of social protection mostly reflects the short-term and temporary nature of the work of a large proportion of migrants, which indicates that a significant part of external migration is reversible [28, p. 3].

External labor migration has both positive and negative consequences for the Ukrainian economy, although the lack of reliable data on the volume of migration flows from Ukraine does not allow to draw unambiguous conclusions about the resulting effect. However, given that the bulk of the migration flow from Ukraine is short-term and "pendulum", it can be assumed that at this stage the net economic effects of increasing migration are positive. Migrants bring or transfer to Ukraine the funds earned abroad, which amount to $7.6-8.4 \%$ of GDP annually and many times exceed the volume of foreign direct investment. These funds support the national currency exchange rate and finance household consumption. The most significant negative factors include imbalances in the labor market, increased expectations of workers about wages, possible deepening of income inequality between households, inefficient use of public funds for social protection [28, p. 3].

EU countries, especially new members, are interested in Ukrainian labor migrants and only a well-thought-out state policy will be able to stop the threatening process of loss of domestic labor, while creating adequate protection for citizens who prefer to work abroad [3]. Given the current trends in migration processes, state policy in the field of migration policy in the field of migration should be comprehensive and include, in particular, the following areas: 1) collection of information on migration (will develop effective policies and change it depending on changes in migration structure); 2) increase of positive short- and long-term effects from 
migration (simplification of barriers for short-term and pendulum migration, maintenance of communication with migrants, its use for development of trade relations with recipient countries and study of investment opportunities); 3) stimulating internal migration; 4) promoting the development of international cooperation in the field of migration [28, p. 4]. It is also important to legislate the social protection of working Ukrainians abroad, to accelerate the signing of interstate agreements on the legitimate employment of Ukrainian labor migrants [3]. State migration policy should also be part of the program of measures to preserve and develop labor potential.

Particular attention should be paid to the issue of educational migration, because, in contrast to labor migration, which is often shortterm, pendulum, educational migration often results in further longterm labor migration. As S.O. Stepurina, V.I. Derykhovska emphasize, foreigners - graduates seek for professional realization in the country where they receive education, because it is educational migrants who have lived for a certain period of time in the country - importer of educational services, much easier to adapt to living conditions, legislation, language policy and other socio-economic features [30, p. 498]. For example, according to official US statistics, almost $25 \%$ of highly skilled migrant workers studied in this country [31].

Educational migration in Ukraine has been a characteristic feature of mass since 2000 and tends to increase annually in the number of Ukrainian students leaving abroad for education and further employment. Thus, according to the UNESCO Institute of Statistics, only for the period from 2000 to 2012 the number of Ukrainian students abroad increased more than four times and reached 37 thousand people [30, p. 499-500]. In 2015-2016, 66,688 Ukrainian citizens received higher education outside our country, the most desirable continue to be free of charge in Poland, where $45.4 \%$ study, in the Eurozone countries: Italy, Germany, the Czech Republic, France, Austria, Spain and Hungary (more than 37\%), Russia (almost $11 \%$ ) and the United States, Canada or Australia (up to 7\%). In general, the dynamics of the number of domestic students abroad over the past eight years (2010-2017 - author's note) was 176\% [32].

At the same time, there is a tendency for domestic scientists to migrate abroad. G.V. Smaliychuk notes that the largest number of candidates of science under the age of 40 go to the United States, Germany, Canada, Russia 
[33]. According to the CEDOS think tank, in 2014-2016 alone, twice as many Ukrainians went to the Czech Republic and Switzerland for a degree, the number of young scientists in Poland increased by 40\%, and in 2009-2016 the growth of Ukrainian graduate students in Germany was 20\% [32]. Such trends have a negative impact on the preservation and, especially, the development of Ukraine's labor potential. After all, it is not just about the outflow of skilled workers, but also about the reduction of intellectual potential in general. It is necessary to agree with the position of S.O. Stepurina, V.I. Derikhovska, that the countries - donors of intellectual capital face serious challenges and threats to economic security, including the risks of loss of labor potential and the transition of educational migration to labor emigration, deteriorating population structure due to increasing average age of the working population. There is also a threat associated with slowing down the development of scientific and technological progress, because the possible «brain drain», ie the country loses its intellectual potential, which, in turn, slows down the country's innovative development, delays economic growth [30, p. 499].

Experts of the CEDOS think tank, which collects and analyzes data on the number of domestic students studying at foreign universities, point out that the main reasons for Ukrainian students to go to study are the following: 1) opportunities to study at home are limited, but the return on education at home is high, so they get the desired education and return home; 2) there are opportunities to study at home, but the return on education is lower than in the destination country, so they go to study abroad with the intention of staying there for permanent residence. At the same time, the second case predominates in the motivation of Ukrainian students to study abroad [32].

In contrast to Ukraine's imperfect state policy in the field of education in Europe, Russia and the United States pursue a systematic policy of attracting Ukrainians to study in various programs (short-term (semester, annual) internships, bachelor's and master's programs, doctoral studies, postdoctoral programs). Thus, Polish universities, having begun to feel the outflow of students due to demographic reasons in the late 1990s and early 2000s, began to be active in foreign education markets. The Polish government was one of the first in the 1990s to launch several scholarship programs to teach Ukrainians, and the number of such educational opportunities is growing every year. In addition, foreign students in Poland have a work permit, which is another advantage of studying in Poland. This is an example of the fact 
that a moderate and purposeful state policy in the field of education and international relations gives an increase in immigrants, minimizes losses from emigration of Poles to other countries of the European Union [34, p. 6].

Instead, Ukraine does not have a purposeful state policy in the field of education, in addition, there is no registration of students studying abroad and statistics on their return after school. We agree with P.G. Bezuglyi, that the state policy in the field of education in Ukraine during the 1990s and to this day intensifies external educational migration, the outflow of students to study abroad [33, p. 6]. Accordingly, along with the reform of the education system, improving the quality of educational services, it is necessary, as rightly pointed out by S.O. Stepurina, V.I. Derikhovska, promoting the reintegration of educational migrants (by creating favorable conditions for professional realization and a decent standard of living for students who have already received or are receiving education abroad, for their return home), balancing educational migration to increase exports of educational services, strengthening control over activities educational recruiters who represent the interests of foreign free economic zones and promote the outflow of Ukrainian students abroad) [30, p. 504, 503]. Of course, the Ukrainian state must effectively use the economic and social benefits provided by educational migration, but it is important to adhere to national priorities and move towards the export of educational services [30, p. 504].

\section{Conclusions}

Therefore, in order to preserve and develop the labor potential of Ukraine, it is important to develop and ensure the implementation of a comprehensive "Program for the preservation and development of labor potential of Ukraine". The directions of the state policy in this sphere should provide purposeful influence on the factors promoting development of labor potential, and include the following components:

1. The normative component determines the legal provision for the preservation and development of labor potential. It is based on labor and social legislation that establishes the level of protection of persons who exercise or may exercise their right to work in the future. At the same time, the normative component is the whole set of normative-legal acts that will regulate practical steps to the preservation and development of labor potential, including the definition of state policy in this direction. 
2. The economic component includes the analysis of economic policy of the state as a whole; determining the economic opportunities of society and the individual in Ukraine, their relationship with similar opportunities that exist in the realization of the labor potential of the individual abroad; establishment of favorable and unfavorable conditions that affect the development of labor potential of the state and society.

3. The educational component provides an analysis of the market of educational services, its compliance with the requirements and challenges of the labor market; determination of qualification requirements and skills of graduates, most necessary from the position of the employer; establishing ways to balance supply and demand in the labor market through educational policy, in particular, shifting the emphasis from the theoretical to the practical component of training within vocational and higher education; development of an adult education program (lifelong learning). An important area of educational policy is measures aimed at reducing the level of educational migration.

4. The migration component is an analysis of the migration policy of Ukraine and identification of ways to reduce the level of labor migration of workers and the outflow of qualified personnel.

5. The demographic component includes identifying ways to improve the demographic situation of Ukraine and its individual regions as a factor that directly affects the labor potential of the state in the future. It also includes health policy, in particular, the study of factors influencing the health of the population, ways to improve the quality and accessibility of medical services, the introduction of compulsory state health insurance.

\section{References:}

1. Kolos Ju.Ju. (2009). Trudovyj potencial Ukrainy: vyznachennja ta rozvytok [Labor potential of Ukraine: definition and development]. Naukovi praci Kirovogradskogo nacionalnogo tehnichnogo universytetu. Ekonomichni nauky [Scientific works of Kirovograd National Technical University. Economic sciences], vol. 15, pp. 225-229. (in Ukrainian)

2. Sokolov A.V. (2015). Trudovi resursy jak chynnyk vplyvu na stijkyj socialno-ekonomichnyj rozvytok [Labor resources as a factor influencing sustainable socio-economic development]. Derzhava ta regiony. Serija: Ekonomika ta pidpryjemnyctvo [State and regions. Series: Economics and Entrepreneurship], no. 5(86), pp. 10-14. (in Ukrainian)

3. Kravchenko M.V.(2007). Problemy ta perspektyvy rozvytku trudovogo potencialu Ukrainy: regionalnyj vymir [Problems and prospects of labor potential deve- 
lopment of Ukraine: regional dimension]. Derzhavne budivnyctvo [State building], no. 1(2). Retrieved from: http://nbuv.gov.ua/UJRN/DeBu_2007_1\%282\%29_22 (accessed 15.10.2020). (in Ukrainian)

4. Koncepcija Zagalnoderzhavnoi cilovoi socialnoi programy zberezhennja i rozvytku trudovogo potencialu Ukrainy na period do 2017 roku [The concept of the National target social program for the preservation and development of labor potential of Ukraine for the period up to 2017]: rozporjadzhennja Kabinetu Ministriv Ukrainy vid 22.07.2009 no. 851-r. Retrieved from: https://www.kmu.gov.ua/ua/ npas/230430428 (accessed 15.10.2020). (in Ukrainian)

5. Pro zberezhennja ta rozvytok trudovogo potencialu Ukrainy [On preservation and development of labor potential of Ukraine]: Rishennja Nacionalnoi trystoronnoi socialno-ekonomichnoi rady vid 05.04.2018 no. 1. Retrieved from: http://www.ntser.gov.ua/sessions-materials/25 (accessed 15.10.2020). (in Ukrainian).

6. Zajnjatist naselennja za stattju, typom miscevosti ta vikovymy grupamy (2019-2020 rr.) [Employment of the population by sex, type of area and age groups (2019-2020)]. Retrieved from: http://www.ukrstat.gov.ua (accessed 15.10.2020). (in Ukrainian)

7. Bezrobittja naselennja (za metodologijeju MOP) za stattju, typom miscevosti ta vikovymy grupamy (2019-2020 rr.) [Unemployment of the population (according to the ILO methodology) by sex, type of area and age groups (2019-2020)]. Retrieved from: http://www.ukrstat.gov.ua (accessed 15.10.2020). (in Ukrainian)

8. Makroekonomichnyj analiz ta prognozuvannja [Macroeconomic analysis and forecasting] / Ministerstvo ekonomichnogo rozvytku i torgivli Ukrainy. Retrieved from: https://www.me.gov.ua/Tags/DocumentsByTag?lang=uk-UA\&id= 46442994-b673-481b-bdf4-8941551bc942\&tag=EkonomichnaSituatsiiaTaMakroekonomichnePrognozuvannia (accessed 15.10.2020). (in Ukrainian)

9. Vinichuk M.V. (2013). Reguljuvannja zajnjatosti naselennja jak mehanizm zabezpechennja socialnoi bezpeky derzhavy [Regulation of employment as a mechanism for ensuring social security of the state]. Naukovyj visnyk Lvivskogo derzhavnogo universytetu vnutrishnih sprav. Serija ekonomichna [Scientific Bulletin of Lviv State University of Internal Affairs. The series is economic], no. 1, pp. 21-33. (in Ukrainian)

10. Pro osnovni naprjamy rozvytku trudovogo potencialu na period do 2010 roku (1999) [On the main directions of development of labor potential for the period up to 2010]: Ukaz Prezydenta Ukrainy vid 03.08.1999 № 959/99. Oficijnyj visnyk Ukrainy [Official Gazette of Ukraine], no. 31, Art. 1608. (in Ukrainian)

11.Zvit «Nezadeklarovana pracja v Ukraini: formy projavu, masshtaby ta shljahy ii podolannja» [Report «Undeclared work in Ukraine: forms of manifestation, scale and ways to overcome it»] (2018). Retrieved from: http://dsp.gov.ua/ wp-content/uploads/2018/05/protydija-nezadeklarovanij-praci-1.pdf (accessed 15.10.2020). (in Ukrainian)

12. Torzhevskyj M.V. (2017). Detinizacija zajnjatosti naselennja v Ukraini [De-shadowing of employment in Ukraine] (PhD Thesis), Kyiv, 218 p. (in Ukrainian)

13. Eurostat. Disparities in minimum wages across the EU. Retrieved from: https://ec.europa.eu/eurostat/en/web/products-eurostat-news/-/DDN-20200203-2 (accessed 15.10.2020). 
14.Pro vnesennja zmin do dejakyh zakonodavchyh aktiv Ukrainy [On Amendments to Certain Legislative Acts of Ukraine]: Zakon Ukrainy vid 06.12.2016 no. 1774-VIII. Vidomosti Verhovnoi Rady [Information of the Verkhovna Rada], 2017, no. 2, art. 25. (in Ukrainian)

15.Lopushnjak G.S. (2017). Minimalna zarobitna plata: praktyka Ukrainy ta dosvid krain Jevropejskogo Sojuzu [Minimum wage: the practice of Ukraine and the experience of the European Union]. Demografija ta socialna ekonomika [Demography and social economy], no. 1, pp. 132-144. (in Ukrainian)

16. Eksport i zarplaty zrostajut, a subsydij stalo bilshe: jak NBU bachyt zhyttja v Ukraini [Exports and wages are rising, and subsidies have become more: how the NBU sees life in Ukraine]. Retrieved from: https://ukr.segodnya.ua/economics/enews/eksport-i-zarplaty-rastut-a-subsidiy-nuzhno-vse-bolshe-kak-nbu-viditzhizn-v-ukraine-1111375.html (accessed 15.10.2020). (in Ukrainian)

17. Prozhytkovyj minimum v Ukraini [Subsistence level in Ukraine]. Retrieved from: https://index.minfin.com.ua/ua/labour/wagemin/ (accessed 15.10.2020). (in Ukrainian)

18. Inshyn M.I., Macjuk A.R., Sockyj A.M., Shherbyna V.I. (2011). Kurs porivnjalnogo trudovogo prava [Course of comparative labor law. Kharkiv: Nicka Nova, 980 p. (in Ukrainian)

19. Vyshnovecka S.V. (2017). Osnovni faktory, shho skladajut zagrozu bezpeci pracivnyka pid chas trudovoi dijalnosti [The main factors that threaten the safety of the employee during employment]. Socialne pravo [Social law], no. 2, pp. 30-37. (in Ukrainian)

20. Saharuk I.S. (2012). Nedopushhennja dyskryminacii u sferi praci jak pryncyp trudovogo prava [Prevention of discrimination in the field of labor as a principle of labor law] (PhD Thesis), Kyiv: Taras Shevchenko National Univercity of Kyiv, 230 p. (in Ukrainian)

21. Bilorus T. (2012). Trudovyj potencial Ukrainy: suchasnyj stan ta perspektyvy rozvytku [Labor potential of Ukraine: current state and prospects of development]. Visnyk Kyivskogo nacionalnogo universytetu imeni Tarasa Shevchenka. Ekonomika [Bulletin of Taras Shevchenko National University of Kyiv. Economy], no. 137 , pp. 42-45. (in Ukrainian)

22. Skoryk T.V. (2016). Osvita vprodovzh zhyttja v konteksti jevrointegracijnyh procesiv [Lifelong learning in the context of European integration processes]. Visnyk Chernigivskogo nacionalnogo pedagogichnogo universytetu im.T.G.Shevchenka. Serija: Pedagogichni nauky [Bulletin of Taras Shevchenko National Pedagogical University. Series: Pedagogical sciences], no. 135, pp. 232-235. (in Ukrainian)

23. Karpenko M. Osvita protjagom zhyttja: svitovyj dosvid i ukrainska praktyka: analitychna zapyska [Lifelong learning: world experience and Ukrainian practice. Analytical note]. Retrieved from: http://www.niss.gov.ua/articles/252/ (accessed 15.10.2020). (in Ukrainian)

24.Pro osvitu [On education]: Zakon Ukrainy vid 05.09.2017. Vidomosti Verhovnoi Rady Ukrainy [Information of the Verkhovna Rada of Ukraine], 2017, no. 38-39, art. 380. (in Ukrainian)

25. Kozlovska G.V. (2008). Bezperervna osvita v Jevropi ta Ukraini: sociologichnyj analiz [Continuing education in Europe and Ukraine: a sociological ana- 
lysis]. Naukovyj chasopys NPU imeni M.P. Dragomanova. Serija 11. Sociologija. Socialna robota. Socialna pedagogika. Upravlinnja [Scientific journal of NPU named after M.P. Drahomanov. Series 11. Sociology. Social work. Social pedagogy. Management], no. 7, pp. 13-20. (in Ukrainian)

26. Palijenko O.A. (2017). Demografichna kryza v Ukraini: shljahy ii podolannja [Demographic crisis in Ukraine: ways to overcome it]. Molodyj vchenyj [Young Scientist], no. 9.1 (49.1), pp. 133-136. (in Ukrainian)

27.Palazhij G. Trudova ta osvitnja migracii z Ukrainy: Jak vtrymaty ljudskyj potencial? [Labor and educational migration from Ukraine: How to maintain human potential?]. Retrieved from: https://zik.ua/news/2018/07/24/trudova_ta_osvitnya_migratsii_z_ukrainy_yak_vtrymaty_lyudskyy_potentsial_1372513 (accessed 15.10.2020). (in Ükrainian)

28. Centr ukrainskoi strategii (2018). Skilky ukrainciv poihalo za kordon i shho derzhavi z cym robyty: analitychna zapyska [How many Ukrainians went abroad and what should the state do about it: an analytical note]. Retrieved from: https://ces.org.ua/ wp-content/uploads/2018/04/Migration-note.pdf (accessed 15.10.2020). (in Ukrainian)

29. Sociologichna grupa «Rejtyng». Dynamika migracijnyh nastroiv ukrainciv [Dynamics of migration sentiments of Ukrainians]. Retrieved from: http://ratinggroup.ua/research/ukraine/dinamika_migracionnyh_nastroeniy_ ukraincev.html (accessed 15.10.2020). (in Ukrainian)

30. Stepurina S.O., Deryhovska V.I. (2018). Tendencii osvitnoi migracii ta ii vplyv na instytucijne seredovyshhe $\mathrm{v}$ Ukraini [Trends in educational migration and its impact on the institutional environment in Ukraine]. Ekonomika ta suspilstvo [Economy and society], no. 17, pp. 496-505. (in Ukrainian)

31.Zhurakovska L.A. (2014). Tendencii osvitnoi migracii v konteksti globalizacii ekonomichnogo rozvytku [Trends in educational migration in the context of globalization of economic development]. Demografija ta socialna ekonomika [Demography and social economy], no. 1(21). Retrieved from: https://dse.org.ua/ arhcive/21/20.pdf (accessed 15.10.2020). (in Ukrainian)

32. Slobodjan O., Stadnyj Je. (2017). Ukrainski studenty za kordonom: fakty ta stereotypy [Ukrainian students abroad: facts and stereotypes]. Retrieved from: https://cedos.org.ua/uk/articles/ukrainski-studenty-za-kordonom-fakty-ta-stereotypy (accessed 15.10.2020). (in Ukrainian)

33. Smalijchuk G.V. (2014). Osvitnja migracija v umovah transformacii rynku praci: znachennja ta osoblyvosti reguljuvannja [Educational migration in the conditions of labor market transformation: significance and features of regulation]. Naukovyj chasopys NPU imeni M.P. Dragomanova. Serija 18: Ekonomika i pravo [Scientific journal of NPU named after M.P. Drahomanov. Series 18: Economics and Law], vol. 26, pp.64-70. Retrieved from: http://nbuv.gov.ua/UJRN/ Nchnpu_018_2014_26_11 (accessed 15.10.2020). (in Ukrainian)

34. Bezuglyj P. $\bar{G}$. (2017). Migracija jak rezultat derzhavnoi osvitnoi polityky v Ukraini za chasiv nezalezhnosti [Migration as a result of state educational policy in Ukraine since independence]. Politychne zhyttja [Political life], no. 4, pp. 4-7. 